\title{
PENGARUH PELAKSANAAN KESELAMATAN DAN KESEHATAN KERJA TERHADAP KINERJA PEGAWAI KANTOR DISTRIK NAVIGASI KELAS I PALEMBANG DIREKTORAT JENDERAL PERHUBUNGAN LAUT KEMENTERIAN PERHUBUNGAN
}

\author{
${ }^{1}$ Amriyadi, ${ }^{2}$ Luis Marnisah, ${ }^{3}$ Fakhry Zamzam \\ ${ }^{1}$ Mahasiswa Program Magister Universitas IGM, Email: amry.dispal@gmail.com \\ ${ }^{2}$ Program Magister Universitas IGM, Email: luismarnisah@uigm.ac.id \\ ${ }^{3}$ Program Magister Universitas IGM, Email: fakhry@uigm.ac.id
}

\begin{abstract}
The purpose of this study was to obtain a detailed description of the effect of occupational safety and health of employees at the Palembang Class I Navigation District Office of the Directorate General of Sea Transportation, Ministry of Transportation, with quantitative analysis, using SPSS statistical tools, 20 using quantitative descriptive methods, the number of respondents 44 employees at the locus. research. The results showed that partially occupational safety and occupational health variables had a positive and significant effect, and simultaneously the effect of work safety and occupational health together had an effect on employee performance, but partially occupational health was more dominant in influencing employee performance. It is suggested that in order to achieve good performance related to $K 3$, then the health factor is prioritized, then work safety.
\end{abstract}

Keywords: Occupational Safety, Occupational Health and Performance.

\begin{abstract}
ABSTRAK
Tujuan Penelitian ini untuk mendapatkan gambaran secara terinci pengaruh Keselamatan dan Kesehatan Kerja Pegawai pada Kantor Distrik Navigasi Kelas I Palembang Direktorat Jenederal Perhubungan Laut Kementerian Perhubungan, dengan Analisis Kuantitatif, menggunakan alat statistik SPSS, 20 menggunakan Metode Deskriftif kuantitatif, jumlah responden 44 orang Pegawai pada lokus penelitian. Hasil Penelitian diperoleh bahwa secara parsial variabel Keselamatan kerja dan Kesehatan kerja berpengaruh positif dan signifikan, dan secara simultan pengaruh antara Keselatan kerja dan Kesehatan kerja secara bersama-sama berpengaruh terhadap Kinerja Pegawai, namun secara parsial Kesehatan kerja lebih dominan mempengaruh Kinerja pegawai. Disarankan bahwa untu mewujudkan Kinerja yang baik berkaitan dengan K3, maka faktor Kesehatan lebih di utamakan, kemudian Keselatan kerja.
\end{abstract}

Kata Kunci: Keselamatan Kerja, Kesehatan Kerja dan Kinerja.

\section{A. PENDAhuluan}

\section{Latar Belakang}

Permasalahan Keselamatan dan Kesehatan Kerja (K3) secara umum di Indonesia masih terabaikan, hal ini ditunjukan dengan angka kecelakaan yang masih tinggi dan tingkat kepedulian dunia usaha terhadap keselamatan kerja yang masih rendah (Yusmiyanti 2008). Sehingga Keselamatan dan Kesehatan Kerja (K3) menjadi sangat penting bagi perusahaan dikarenakan kecelakaan kerja pada perusahaan tidak hanya merugikan karyawan tetapi juga perusahaan baik secara langsung maupun tidak langsung

Faktor penyebab terjadinya kecelakaan kerja dalam suatu perusahaan antara lain umur, masa kerja, tingkat pendidikan, penggunaan alat perlindungan diri (APD), karakteristik kepribadian, pelatihan $\mathrm{K} 3$, dan suhu ruangan (Afini 2011). Dari faktorfaktor penyebab terjadinya kecelakaan kerja menunjukkan bahwa kecelakaan kerja terjadi umumnya lebih 
disebabkan oleh kesalahan manusia (human error).

Keselamatan dan Kesehatan Kerja merupakan komponen penting dalam setiap proses pekerjaan termasuk pada bidang konstruksi jalan raya. Pengetahuan, pemahaman, perilaku, kesadaran, sikap dan tindakan tenaga kerja dalam upaya mengimplementasikan K3 masih sangat rendah dan belum ditempatkan sebagai suatu kebutuhan pokok bagi peningkatan kesejahteraan secara menyeluruh termasukpeningkatan produktivitas kerja. K3 dalam pekerjaan konstruksi merupakan suatusubyek yang oleh sebagian besar kalangan hanya dijadikan untuk bahan percakapanselingan saja. Fakta menunjukkan bahwa proses pelaksanaan konstruksi jalan raya termasuk pekerjaan yang berbahaya. Kegiatan jasa konstruksi bidang jalan raya terdiri dari berbagai kegiatan rawan kecelakaan dan dalam melakukan aktivitasnya memerlukan sumber daya manusia yang mendukung usaha pencapaian tujuan yang telah ditetapkan. Bagaimanapun lengkap dan canggihnya sumber-sumber daya nonmanusia yang dimiliki oleh suatu perusahaan, tidaklah menjadi jaminan bagi 2 perusahaan tersebut untuk mencapai suatu keberhasilan dalam hal keselamatan kerja.

Suma'mur P.K (2009) menganggap suatu kecelakaan disebabkan oleh tindakan pekerja yang salah. Tetapi pada saat ini anggapan tersebut telah bergeser, bahwa kecelakaan kerja bersumber kepada faktor-faktor organisasi dan manajemen. Distrik Navigasi kelas I Palembang adalah Unit Pelaksana Teknis Direktorat

Kenavigasian Direktorat Jendral Perhubungan Laut, yang memiliki tugas pokok Melaksanakan perencanaan pengoperasian, pengadaan, dan pengawasan Sarana Bantu Navigasi Pelayaran, Telekomunikasi Pelayaran, serta kegiatan Pengamatan Laut, Survey Hidrografi, Pemantauan Alur dan Perlintasan dengan menggunakan sarana instalasi untuk kepentingan keselamatan pelayaran.

Dirjen Navigasi kelas I Direktorat Jenderal Perhubungan Laut Palembang, memiliki resiko keselamatan dan kesehatan kerja, jika tempat kerja aman dan sehat, setiap orang dapat melanjutkan pekerjaan mereka secara efektif dan efisien. Sebaliknya, jika tempat kerja tidak terorganisir dan banyak terdapat bahaya, kerusakan dan absen sakit tak terhindarkan, mengakibatkan hilangnya pendapatan bagi pekerja dan produktivitas berkurang bagi perusahaan. Meskipun kenyataannya, para pengusaha di seluruh dunia telah secara hatihati merencanakan strategi bisnis mereka, banyak yang masih mengabaikan masalah penting seperti keselamatan, kesehatan dan kondisi kerja. Biaya untuk manusia dan finansial dianggap besar.

Keselamatan dan Kesehatan Kerja (K3) karyawan merupakan salah satu factor penting untuk menujang keberhasilan suatu perusahaan, karena dampak kecelakaan dan penyakit kerja tidak hanya merugikan karyawan, tetapi juga perusahaan baik secara langsung maupun tidak langsungz (Kusuma, 2001), pada kenyataannya tingkat kecelakaan kerja di Indonesiamasih tergolong tinggi dibandingkan dengan negara lain. Bahkan dari tahun ketahun angka kecelakaan kerja terus meningkat.

Hasil penelitian yang diadakan ILO (Organisasi perburuhan internasional) mengenai standar kecelakaan kerja menyatakan bahwa Indonesia menempati urutan ke 152 dari 153 negara yang ditelitinya. Hal ini menunjukan bahwa di Indonesia, tingkat kepedulian sektor industri terhadap Keselamatan dan Kesehatan Kerja (K3) masih rendah. Padahal karyawan merupakan aset penting perusahaan. Dilihat dari jumlah kecelakaan kerja yang meningkat dari tahun ke tahun menunjukkan bahwa sistem Manajemen Keselamatan dan Kesehatan Kerja belum benar benar diterapkan dan sampai kapasitasnya.

Keselamatan dan Kesehatan Kerja (K3) menurut Hendara (2002) upaya untuk menjaga dan meningkatkan status kesehatan pekerja pada tingkat tertinggi dan terbebas dari faktorfaktor dilingkungan kerja yang dapat menyebabkan terjadinya. Gangguan kesehatan. Kesehatan adalah merujuk pada konsisi umum fisik, mental dan stabilitas emosi secara umum. Keselamatan dan Kesehatan Kerja (K3) dijadikan sebagai aspek perlindungan tenaga kerja sekaligus melindungi asset perusahaan yang bertujuan sedapat mungkin memberikan 
jaminan kondisi yang aman dan sehat kepada setiap karyawan.

\section{Perumusan Masalah}

Berdasarkan latar belakang dan identifikasi masalah dalam penelitian ini maka, rumusan masalah dalam penelitian ini adalah

1. Bagaimanakah pengaruh factor krselamatan kerja terhadap kinerja karyawan di Kantor Distrik Navigasi kelas I Palembang?

2. Bagaimanakah pengaruh kesehatan terhadap kinerja karyawan di Kantor Distik Navigasi kelas I Palembang?

3. Bagaimana pengaruh keselamatan dan kesehatan kerja terhadap terhadap kinerja karyawan di Kantor Distrik Navigasi kelas I Palembang?

\section{B. TINJAUAN PUSTAKA}

\subsection{Keselamatan Kerja}

Menurut Ernawati (2009), keselamatan kerja adalah keselamatan yang berhubungan dengan peralatan, tempat kerja dan lingkungan, serta cara-caramelakukan pekerjaan. Keselamatan kerja menjadi aspek yang sangat penting, mengingat resiko bahayanya dalam penerapan teknologi. Keselamatan kerjamerupakan tugas semua orang yang bekerja, setiap tenaga kerja dan juga masyarakat pada umumnya.

Menurut

Suma'mur

mendefinisikan Keselamatan kerja merupakan rangkaian usaha untuk menciptakan suasana kerja yang aman dan tentram bagi para karyawan yang bekerja di perusahaan yang bersangkutan. Menurut Mathis dan Jackson (2002), bahwa definisikan keselamatan adalah merujuk pada perlindungan terhadap kesejahteraan fisik seseorang terhadap cedera yang terkait dengan pekerjaan.

\subsection{Kecelakaan Kerja}

Menurut Rika Ampuh Hadiguna (2009), kecelakaan kerja merupakan kecelakaan seseorang atau kelompok dalam rangka melaksanakan kerja di lingkungan perusahaan, yang terjadi secara tiba-tiba, tidak diduga sebelumnya, tidak diharapkan terjadi, menimbulkan kerugian ringan sampai yang paling berat, dan bisa menghentikan kegiatan pabrik secara total. Penyebab kecelakaan kerja dapat dikategorikan menjadi dua:

1. Kecelakaan yang disebabkan oleh tindakan manusia yang tidak melakukan tindakan penyelamatan. Contohnya, pakaian kerja, penggunaan peralatan pelindung diri, falsafah perusahaan, dan lain-lain.

2. Kecelakaan yang disebabkan oleh keadaan lingkungan kerja yang tidak aman.

Contohnya, penerangan, sirkulasi udara, temperatur, kebisingan, getaran, penggunaan indikator warna, tanda peringatan, sistem upah, jadwal kerja, dan lain-lain (Rika Ampuh Hadiguna, 2009).

\subsection{Kesehatan Kerja}

Menurut Mangkunegara (2011) Program kesehatan kerja menunjukkan pada kondisi yang bebas dari gangguan fisik, mental, emosi atau rasa sakit yang disebabkan oleh lingkungan kerja. Resiko kesehatan merupakan faktor-faktor dalam lingkungan kerja yang bekerja melebihi periode waktu yang ditentukan, Lingkungan yang dapat membuat stress emosi atau gangguan fisik. Menurut Moenir (2006) yang dimaksud kesehatan kerja adalah suatu usaha dan keadaan yang memungkinkan seseorang mempertahankan kondisi kesehatannya dalam pekerjaan. Menurut Silalahi dan Rumondang (2000) menyatakan kesehatan kerja yaitu terhindarnya dari penyakit yang mungkin akan timbul setelah memulai pekerjaannya.

Kesehatan kerja adalah bagian dari ilmu kesehatan yang bertujuan agar tenaga kerja memperoleh keadaan kesehatan yang sempurna baik fisik, mental maupunsosial (Lalu Husni, 2005). Selain itu, kesehatan kerja menunjuk pada kondisi fisik, mental dan stabilitas emosi secara umum dengan tujuan memelihara kesejahteraan individu secara menyeluruh (Malthis dan Jackson, 2002). Sedangkan menurut Prabu Mangkunegara (2001) pengertian kesehatan kerja adalah kondisi bebas dari gangguan fisik, mental, emosi atau rasa sakit yang disebakan lingkungan kerja 


\subsection{Kinerja}

Beberapa ahli mengemukakan pengertian kinerja diantaranya: Kinerja adalah kesediaan seseorang atau kelompok orang untuk melakukan kegiatan atau menyempurnakannya sesuai dengan tanggungjawabnya dengan hasil seperti yang diharapkan (Daryanto dan Bintoro 2017: 105).

Menurut Benardin dan Russel dalam Donni Juni Priansa (2017:270), kinerja merupakan hasil yang diproduksi oleh fungsi pekerjaan tertentu atau kegiatan-kegiatan pada pekerjaan tertentu selama periode waktu tertentu. Hasil kerja tersebut merupakan hasil dari kemampuan, keahlian, dan keinginan yang dicapai.

\subsection{Program Keselamatan dan Kesehatan Kerja (K3)}

Menurut Rizky Argama (2006), program Keselamatan dan Kesehatan Kerja (K3) adalah suatu sistem program yang dibuat bagi pekerja maupun pengusaha sebagai upaya pencegahan (preventif) timbulnya kecelakaan dan penyakit kerja akibat hubungan kerja dalam lingkungan kerja dengan cara mengenali hal-hal yang berpotensi menimbulkan kecelakaan dan penyakit kerja akibat hubungan kerja, dan tindakan antisipatif bila terjadi hal demikian. Program Keselamatan dan Kesehatan Kerja (K3) adalah suatu sistem yang dirancang untuk menjamin keselamatan yang baik pada semua personel di tempatkerja agar tidak menderita luka maupun menyebabkan penyakit di tempat kerja dengan mematuhi/ taat pada hukum dan aturan keselamatan dan kesehatan kerja, yang tercermin pada perubahan sikap menuju keselamatan di tempat kerja (Rijuna Dewi, 2006).

\subsection{Penelitian Terdahulu}

M.Dimas Prawita Komandan dkk. Melakukan penelitianberjudul "Pengaruh Sistem Manajemen Keselamatan dan Kesehatan Kerja (SMK3) Terhadap Kinerja Karyawan PT Adhi Karya (Persero) Tbk." Hasil penelitian menunjukan bahwa Sistem Manajemen Kesehatan dan Keselamatan Kerja memiliki pengaruh positif dan signifikan terhadap kinerja karyawan.
Noetty, dkk. mahasiswa FISIP UI,2013. Melakukan penelitian yang berjudul "Pengaruh Pelaksanaan Sistem Manajemen Keselamatan dan Kesehatan Kerja (SMK3) Terhadap Kinerja Karyawan Bagian Produksi PT. Holcim Indonesia Tbk Narogong". Hasil penelitian menunjukan bahwa terdapat pengaruh signifikan dan positif antara pelaksanaan system manajemen keselamatan dan kesehatan kerja (SMK3) dengan kinerja karyawan bagian produksi.

Desi Supriyan dkk, (2017) Melakukan penelitian yang berjudul "Pengaruh Manajemen K3 dan Budaya K3 Terhadap Kinerja Pekerja Proyek" (Studi kasus Proyek Pembangunan Cengkareng Business City Lot 5). Hasil penelitian menunjukan bahwa secara parsial variabel independen yaitu Penerapan Manajemen K3 dan Budaya K3 memiliki pengaruh terhadap Kinerja Pekerja Konstruksi. Selain itu faktor yang lebih dominan bagian dari varibel budaya K3.

\section{METODOLOGI PENELITIAN \\ 3.1 Metode Penelitian}

Dalam penelitian ini, Peneliti mengunakan penelitian jenis kuantitatif, di mana tujuan akhir yang ingin dicapai dalam melakukan penelitian pendekatan kuantitatif adalah menguji teori, membangun fakta, menunjukkan hubungan dan pengaruh serta perbandingan antarvariabel, memberikan deskripsi statistic, menafsir, dan meramalkan hasil. Adapun penjelasan skor jawaban dapat dilihat pada Tabel 3.1, sebagai berikut:

\section{Tabel 3.1}

\begin{tabular}{clc}
\multicolumn{3}{c}{ Alternatif dan Skor Jawaban } \\
\hline No & \multicolumn{1}{c}{ Alternatif Jawaban } & Skor \\
\hline 1 & Sangat Setuju (SS) & 5 \\
2 & Setuju (S) & 4 \\
3 & Netral (N) & 3 \\
4 & Tidak Setuju (TS) & 2 \\
5 & Sangat Tidak Setuju & 1 \\
& (STS) & \\
\hline
\end{tabular}

Sumber: Syofian (2017:50)

\subsection{Populasi dan Sampel}

Populasi dalam penelitian ini adalah Distrik Navigasi Kelas I Palembang Direktorat Jenderal Perhubungan Laut Kementrian Perhubungan. Jadi sampel yang digunakan dalam penelitian adalah karyawan Distrik Navigasi Kelas I Palembang Direktorat 
Jenderal Perhubungan Laut Kementrian Perhubungan.

\subsection{Teknik Pengumpulan Data}

Teknik pengumpulan data dalam penelitian ini adalah:

a. Kuisioner (Angket), merupakan teknik pengumpulan data yang dilakukan dengan cara memberi seperangkat pertanyaan atau pernyataan tertulis kepada responden untuk dijawab (Sugiyono, 2014:142)

b. Wawancara, merupakan teknik pengumpulan data ketika Peneliti melakukan studi pendahuluan untuk menemukan permasalahan yang harus diteliti, dan jika Peneliti ingin mengetahui hal - hal dari responden lebih mendalam dan jumlah respondennya sedikit/kecil.

\subsection{Rencana Analisa Data}

Dalam penelitian ini sebagai penelitian kuantitatif yang akan diuji adalah seberapa besar pengaruh pelaksanaan keselamatan kerja dan kesehatan kerja terhadap kantor Distrik navigasi kelas I Palembang Direktorat Jenderal Perhubungan Laut Kementrian Perhubungan. Pengujian dilakukan untuk mengetahui pengaruh variabel independen $\mathrm{X} 1$ dan $\mathrm{X} 2$ terhadap varibel $\mathrm{Y}$ baik secara parsial maupun simultan, teknik pengolahan data menggunakan aplikasi SPSS 20.

\subsection{Uji Coba Instrumen}

Uji coba instrument yang dilakukan terdiri dari 2 uji coba validitas dan reliabilitas sebagai berikut:

\section{Uji Validitas}

Menurut Syofian (2017:75), validitas adalah kesahihan yang menunjukkan sejauh mana suatu alat ukur mampu mengukur apa yang diukur. Menurut Sambas dan Maman (2017:47), untuk menafsirkan hasil uji validitas, kriteria yang digunakan adalah:

a. Jika nilai hitung $r$ lebih besar $(>)$ dari nilai tabel $r$, maka item angket dinyatakan valid dan dapat dipergunakan.

b. Jika nilai hitung $r$ lebih kecil $(<)$ dari nilai tabel $r$, maka item angket dinyatakan tidak valid dan tidak dapat dipergunakan. c. Nilai tabel $\mathrm{r}$ dapat dilihat pada signifikan (a) $=5 \%$ dan derajat bebas $(\mathrm{db})=\mathrm{n}-2$.

\section{Uji Reliabilitas}

Menurut Syofian, (2017:87), reliabilitas bertujuan untuk mengetahui sejauh mana hasil pengukuran tetap konsisten, apabila dilakukan pengukuran dua kali atau lebih terhadap gejala yang sama dengan menggunakan alat pengukur yang sama pula.

\subsection{Uji Asumsi Klasik}

Adapun uji asumsi klasik yang akan dilakukan adalah uji normalitas dan uji linearitas. Adapun penjelasannya sebagai berikut:

\section{Uji Normalitas}

Menurut Syofian (2017:153), uji normalitas bertujuan untuk mengetahui apakah populasi data berdistribusi normal atau tidak. Uji normalitas yang dilakukan dalam penelitian ini menggunakan uji normalitas "Kolmogorov Smirnov". Pada output, jika nilai "Asymp. Sig. (2-tailed)" baris paling bawah bila signifikan tiap variabel lebih besar dari 0,05 , maka uji normalitasnya terpenuhi.

\section{Uji Linieritas}

Menurut Syofian (2017:178), uji linearitas bertujuan untuk mengetahui apakah antara variabel tak bebas $(\mathrm{Y})$ dan variabel bebas $(\mathrm{X})$ mempunyai hubungan linear. Pada output, jika nilai signifikan Deviation from Linearity pada ANOVA Table lebih besar dari 0,05, maka hubungan independen dan dependen bersifat linear dan uji linearitasnya terpenuhi.

\subsection{Rancangan Pengujian Hipotesis}

Menurut Syofian (2017:125), kegiatan analisis data meliputi pengolahan data dan penyajian data, melakukan perhitungan untuk mendeskripsikan data dan melakukan pengujian hipotesis dengan menggunakan uji statistik yang dibantu dengan menggunakan progam SPSS 20. Adapun uji statistik yang digunakan dalam penelitian ini yaitu uji regresi linear sederhana, uji koefisien korelasi, uji t (parsial), uji koefisien determinasi dan uji $\mathrm{F}$ (simultan). Adapun penjelasannya sebagai berikut: 


\section{Regresi Linear Berganda}

Regresi linear berganda digunakan untuk menganalisa satu variabel terikat dan dua atau lebih variabel bebas. Untuk mencari regresi linear berganda dalam penelitian ini menggunakan rumus persamaan sebagai berikut:

$$
\mathbf{Y}=\mathbf{a}+\mathbf{b}_{1} \mathbf{X}_{1}+\mathbf{b}_{2} \mathbf{X}_{2}
$$

\section{Keterangan:}

$$
\begin{array}{ll}
\mathrm{Y} & =\text { kinerja pegawai } \\
\mathrm{X}_{1} & =\text { keselamatan kerja } \\
\mathrm{X}_{2} & =\text { kesehatan kerja } \\
\mathrm{a} & =\text { konstanta. }
\end{array}
$$$$
b_{1}, b_{2}, b_{3}=\text { koefisien regresi. }
$$

Diuji di tingkat signifikan alpha 0,05

\section{Koefisien Determinasi}

Koefisien determinasi adalah angka yang menyatakan atau digunakan untuk mengetahui kontribusi atau sumbangan yang diberikan oleh sebuah variabel bebas terhadap variabel terikat. Untuk mencari koefisien determinasi menggunakan rumus sebagai berikut:

$$
\mathrm{KD}=(\mathbf{r})^{2} \times 100 \%
$$

Keterangan:

$$
\begin{array}{ll}
\mathrm{KD} & =\text { koefisien determinasi } \\
\mathrm{r} & =\text { koefisien korelasi. }
\end{array}
$$

\section{Uji F (Simultan)}

Uji F (simultan) digunakan untuk melihat pengaruh secara bersama-sama antara dua atau lebih variabel bebas dengan variabel terikat, dipenelitian ini uji $\mathrm{F}$ digunakan untuk menguji pengaruh keselamatan kerja dan kesehatan kerja terhadap kinerja pegawai, dalam pengujian ini menggunakan rumus sebagai berikut:

$$
F_{\text {hitung }}=\frac{\left(R_{x 1, x 2, x 3, Y}\right)^{2}(n-m-1)}{m\left(1-R_{X 1, X 2, X 3, Y}^{2}\right)}
$$

Keterangan:

$$
\begin{aligned}
& \mathrm{R}^{2}=\text { koefisien determinasi } \\
& \mathrm{X}_{1}=\text { keselamatan kerja } \\
& \mathrm{X}_{2}=\text { kesehatan kerja } \\
& \mathrm{Y}=\text { kinerja pegawai } \\
& \mathrm{m}=\text { jumlah variabel bebas } \\
& \mathrm{n}=\text { jumlah responden }
\end{aligned}
$$

Untuk mengetahui besarnya nilai yang diperoleh, dengan ketentuan pengujian uji $\mathrm{F}$, sebagai beriku:

$\mathrm{H}_{\mathrm{o}}=0$, Menunjukkan keselamatan kerja dan kesehatan kerja tidak memiliki pengaruh secara simultan terhadap kinerja pegawai di Distrik Navigasi Kelas I Palembang Direktorat Jenderal Perhubungan Laut Kementrian

\begin{tabular}{|c|c|c|}
\hline $\begin{array}{l}\text { Pengujian } \\
\text { Simultan }\end{array}$ & Hipotesis 1 & $\begin{array}{l}\text { Untuk menentukan criteria } \\
\text { penerimaan hipotesis, } \\
\text { apabila } \mathrm{F}_{\text {hitung }}>\mathrm{F}_{\text {tabel maka }} \\
\mathrm{H}_{0} \text { ditolak dan } \mathrm{H}_{\mathrm{a}} \text { diterima, } \\
\text { artinya signifikan, } \\
\text { sedangkan apabila } \mathrm{F}_{\text {hitung }}< \\
\mathrm{F}_{\text {tabel }} \text { maka } \mathrm{H}_{0} \text { diterima dan } \\
\mathrm{H}_{\mathrm{a}} \text { ditolak, artinya tidak } \\
\text { signifikan (usman 2012: } \\
2003 \text { ) }\end{array}$ \\
\hline \multirow[t]{2}{*}{$\begin{array}{l}\text { Pengujian } \\
\text { Parsial }\end{array}$} & Hipotesis 2 & $\begin{array}{l}\mathrm{H}_{0}: \beta=0, \text { tidak terdapat } \\
\text { pengaruh positif } \begin{array}{r}\text { dan } \\
\text { signifikan }\end{array} \\
\text { keselamatan kerja terhadap } \\
\text { kinerja pegawai } \\
\mathrm{H}_{0}: \beta>0 \text {, terdapat pengaruh } \\
\text { positif dan signifikan antara } \\
\text { keselamatan kerja terhadap } \\
\text { kinerja pegawai }\end{array}$ \\
\hline & Hipotesis 3 & $\begin{array}{l}\mathrm{H}_{0}: \beta=0, \text { tidak terdapat } \\
\text { pengaruh positif dan } \\
\text { signifikan antara kesehatab } \\
\text { kerja terhadap kinerja } \\
\text { pegawai } \\
\mathrm{H}_{0}: \beta>0 \text {, terdapat pengaruh } \\
\text { positif dan signifikan antara } \\
\text { kesehatan kerja terhadap } \\
\text { kinerja pegawai }\end{array}$ \\
\hline
\end{tabular}
Perhubungan.

$\mathrm{H}_{\mathrm{a}} \neq 0$, Menunjukkan keselamatan kerja dan kesehatan kerja memiliki pengaruh secara simultan terhadap kinerja pegawai di Distrik Navigasi Kelas I Palembang Direktorat Jenderal Perhubungan Laut Kementrian Perhubungan.

Besarnya nilai dikatakan signifikan apabila $\mathrm{F}_{\text {hitung }}>\mathrm{F}_{\text {tabel, }}$, hal ini berarti $\mathrm{H}_{\mathrm{o}}$ ditolak $\mathrm{H}_{\mathrm{a}}$ diterima dan sebaliknya apabila $\mathrm{F}_{\text {hitung }}<$ $\mathrm{F}_{\text {tabel, }}$ ini berarti $\mathrm{H}_{\mathrm{o}}$ diterima $\mathrm{H}_{\mathrm{a}}$ ditolak.

Tabel 3.3.

\section{Rancangan Pegujian Hipotesis}

\section{HASIL DAN PEMBAHASAN \\ 4.1. Uji Persyaratan Analisis}

Instrumen dikatakan valid jika mampu mengukur apa yang hendak diukur dari variabel yang diteliti. 
a) Uji Validitas

1) Variabel Keselamatan Kerja (X1) Tabel 4.1

Validitas Instrumen Variabel Keselamatan Kerja

\begin{tabular}{|c|c|c|c|c|}
\hline Butir & $\begin{array}{c}\mathbf{r} \\
\text { hitung }\end{array}$ & $\begin{array}{c}\mathbf{r} \\
\text { tabel }\end{array}$ & Keterangan & $\begin{array}{c}\text { Hasil } \\
\text { Uji }\end{array}$ \\
\hline 1 & 0,928 & 0,444 & $\mathrm{r}_{\text {hit }}>\mathrm{r}_{\text {tab }}$ & valid \\
\hline 2 & 0,746 & 0,444 & $\mathrm{r}_{\text {hit }}>\mathrm{r}_{\text {tab }}$ & valid \\
\hline 3 & 0,651 & 0,444 & $\mathrm{r}_{\text {hit }}>\mathrm{r}_{\text {tab }}$ & valid \\
\hline 4 & 0,928 & 0,444 & $\mathrm{r}_{\text {hit }}>\mathrm{r}_{\text {tab }}$ & valid \\
\hline 5 & 0,547 & 0,444 & $\mathrm{r}_{\text {hit }}>\mathrm{r}_{\text {tab }}$ & valid \\
\hline 6 & 0,928 & 0,444 & $\mathrm{r}_{\text {hit }}>\mathrm{r}_{\text {tab }}$ & valid \\
\hline 7 & 0,928 & 0,444 & $\mathrm{r}_{\text {hit }}>\mathrm{r}_{\text {tab }}$ & valid \\
\hline 8 & 0,653 & 0,444 & $\mathrm{r}_{\text {hit }}>\mathrm{r}_{\text {tab }}$ & valid \\
\hline 9 & 0,928 & 0,444 & $\mathrm{r}_{\text {hit }}>\mathrm{r}_{\text {tab }}$ & valid \\
\hline 10 & 0,596 & 0,444 & $\mathrm{r}_{\text {hit }}>\mathrm{r}_{\text {tab }}$ & valid \\
\hline 11 & 0,651 & 0,444 & $\mathrm{r}_{\text {hit }}>\mathrm{r}_{\text {tab }}$ & valid \\
\hline \multicolumn{7}{|c}{ Sumber: Hasil Penelitian Data Tahun } \\
\hline \multicolumn{7}{|c|}{2020} \\
\hline
\end{tabular}
2020

Hasil uji Validitas Variabel Perilaku terdiri dari 11 butir pertanyaan diperoleh $\mathrm{r}_{\text {hit }}$ terkecil 0,547 pada butir nomor 5 dan $r_{\text {hit }}$ terbesar 0,928 pada butir nomor 1,4,6,7,9. Artinya nilai $r_{\text {hit }}>r_{\text {tab }}(\mathrm{df}=18=0,444)$ sehingga dapat disimpulkan bahwa seluruh butir soal variabel Keselamatan $\operatorname{Kerja}(\mathrm{X} 1)$ berstatus valid.

\section{2) Variabel Kesehatan Kerja (X2)}

Tabel 4.2.

Validitas Instrumen Variabel Kesehatan Kerja

\begin{tabular}{|c|c|c|c|c|}
\hline Butir & r hitung & $\mathrm{r}$ tabel & Keterangan & $\begin{array}{c}\text { Hasil } \\
\text { Uji }\end{array}$ \\
\hline 1 & 0,795 & 0,444 & $\mathrm{r}_{\text {hit }}>\mathrm{r}_{\text {tab }}$ & valid \\
\hline 2 & 0,909 & 0,444 & $\mathrm{r}_{\text {hit }}>\mathrm{r}_{\text {tab }}$ & valid \\
\hline 3 & 0,742 & 0,444 & $\mathrm{r}_{\text {hit }}>\mathrm{r}_{\text {tab }}$ & valid \\
\hline 4 & 0,754 & 0,444 & $\mathrm{r}_{\text {hit }}>\mathrm{r}_{\text {tab }}$ & valid \\
\hline 5 & 0,764 & 0,444 & $\mathrm{r}_{\text {hit }}>\mathrm{r}_{\text {tab }}$ & valid \\
\hline 6 & 0,648 & 0,444 & $\mathrm{r}_{\text {hit }}>\mathrm{r}_{\text {tab }}$ & valid \\
\hline 7 & 0,798 & 0,444 & $\mathrm{r}_{\text {hit }}>\mathrm{r}_{\text {tab }}$ & valid \\
\hline 8 & 0,719 & 0,444 & $\mathrm{r}_{\text {hit }}>\mathrm{r}_{\text {tab }}$ & valid \\
\hline 9 & 0,649 & 0,444 & $\mathrm{r}_{\text {hit }}>\mathrm{r}_{\text {tab }}$ & valid \\
\hline 10 & 0,692 & 0,444 & $\mathrm{r}_{\text {hit }}>\mathrm{r}_{\text {tab }}$ & valid \\
\hline
\end{tabular}

Sumber: Hasil Penelitian Data Tahun 2020

Hasil uji Validitas Variabel Komitmen terdiri dari 10 butir pertanyaan diperoleh $\mathrm{r}_{\text {hit }}$ terkecil 0,6483 pada butir nomor 6 dan $r_{\text {hit }}$ terbesar 0,909 pada butir nomor 2. Artinya nilai $r_{\text {hit }}>r_{\text {tab }}(\mathrm{df}=18=0,444)$ sehingga dapat disimpulkan bahwa seluruh butir soal variabel Kesehatan Kerja (X2) berstatus valid.

\section{3) Variabel Kinerja (Y)}

Tabel 4.3

Validitas Instrumen Variabel Kinerja

\begin{tabular}{|c|c|c|c|c|}
\hline Butir & r hitung & $\mathrm{r}$ tabel & Keterangan & $\begin{array}{c}\text { Hasil } \\
\text { Uji }\end{array}$ \\
\hline 1 & 0,524 & 0,444 & $\mathrm{r}_{\text {hit }}>\mathrm{r}_{\text {tab }}$ & valid \\
\hline 2 & 0,622 & 0,444 & $\mathrm{r}_{\text {hit }}>\mathrm{r}_{\text {tab }}$ & valid \\
\hline 3 & 0,532 & 0,444 & $\mathrm{r}_{\text {hit }}>\mathrm{r}_{\text {tab }}$ & valid \\
\hline 4 & 0,706 & 0,444 & $\mathrm{r}_{\text {hit }}>\mathrm{r}_{\text {tab }}$ & valid \\
\hline 5 & 0,595 & 0,444 & $\mathrm{r}_{\text {hit }}>\mathrm{r}_{\text {tab }}$ & valid \\
\hline 6 & 0,540 & 0,444 & $\mathrm{r}_{\text {hit }}>\mathrm{r}_{\text {tab }}$ & valid \\
\hline 7 & 0,671 & 0,444 & $\mathrm{r}_{\text {hit }}>\mathrm{r}_{\text {tab }}$ & valid \\
\hline 8 & 0,757 & 0,444 & $\mathrm{r}_{\text {hit }}>\mathrm{r}_{\text {tab }}$ & valid \\
\hline 9 & 0,570 & 0,444 & $\mathrm{r}_{\text {hit }}>\mathrm{r}_{\text {tab }}$ & valid \\
\hline 10 & 0,706 & 0,444 & $\mathrm{r}_{\text {hit }}>\mathrm{r}_{\text {tab }}$ & valid \\
\hline \multicolumn{7}{|c}{ Sumber: Hasil Penelitian Data Tahun } \\
\hline
\end{tabular}

Hasil uji Validitas Variabel Komitmen terdiri dari 10 butir pertanyaan diperoleh $\mathrm{r}_{\text {hit }}$ terkecil 0,524 pada butir nomor 1 dan $r_{\text {hit }}$ terbesar 0,757 pada butir nomor 8. Artinya nilai $r_{\text {hit }}>r_{\text {tab }}(d f=18=0,444)$ sehingga dapat disimpulkan bahwa seluruh butir soal variabel Kesehatan Kerja (X2) berstatus valid.

\section{b) Uji Reliabilitas}

Tabel 4.4.

Reliabilitas Instrument

\begin{tabular}{|c|c|c|c|}
\hline Variabel & Nilai Alpha & \multicolumn{1}{|c|}{ Keterangan } & Hasil \\
\hline $\begin{array}{c}\text { Keselamatan } \\
\text { Kerja(X1) }\end{array}$ & 0.915 & $\begin{array}{c}\text { Alpha > } \\
0,600\end{array}$ & Reliabel \\
\hline $\begin{array}{c}\text { Kesehatan Kerja } \\
\text { (X2) }\end{array}$ & 0,758 & $\begin{array}{c}\text { Alpha > } \\
0,600\end{array}$ & Reliabel \\
\hline Kinerja (Y) & 0,821 & $\begin{array}{c}\text { Alpha > } \\
0,600\end{array}$ & Reliabel \\
\hline
\end{tabular}

Sumber: Hasil Penelitian Data Tahun 2020

Hasil perhitungan menghasilkan nilai Alpha Cronbach untuk variabel Keselamatan Kerja (X1) sbesar 0,915, variabel Kesehatan Kerja (X2) sebesar 0,758; dan untuk variabel kinerja (Y) adalah 0,821, Perolehan nilai alpha cronbach pada semua variabel lebih besar dari 0,600 sehingga dapat disimpulkan bahwa variabel dalam penelitian ini telah memenuhi syarat reliabilitas intrumen.

\subsection{Hasil Uji Normalitas Data}

Salah satu asumsi yang harus terpenuhi dalam analisis regresi adalah datanya mengikuti Kompensasi normal, sehingga sebelum dilakukan analisis regresi perlu dilakukan uji normalitas data pada masingmasing varibel, yaitu variabel Keselamatan Kerja $\left(\mathrm{X}_{1}\right)$, Kesehatan Kerja $\left(\mathrm{X}_{2}\right)$ dan variabel 
Kinerja(Y). Dalam uji normalitas data ini dilakukan dengan uji Kolmogorov Smirnov dengan hipotesis sebagai berikut:

$\mathrm{H}_{0}$ : Data berdistribusi normal

$\mathrm{H}_{1}$ : Data tidak berdistribusi normal

Statistik uji Kolmogorov Smirnov dihitung dengan bantuan paket program SPSS dan diperoleh nilai sebagai berikut:

\section{Tabel 4.5.}

Hasil Uji Normalitas Data dengan Uji Kolmogorov-Smirnov

\section{One-Sample Kolmogorov-Smirnov Test}

\begin{tabular}{|c|c|c|c|c|}
\hline & & X1 & $\times 2$ & \\
\hline $\bar{N}$ & & 44 & 44 & 44 \\
\hline \multirow[t]{2}{*}{ Normal Parameters } & Mean & 42.59 & 39.00 & 39.36 \\
\hline & Std. Deviation & 4.250 & 5.026 & 3.648 \\
\hline \multirow[t]{3}{*}{ Most Extreme Differences } & Absolute & .129 & .109 & .108 \\
\hline & Positive & .081 & .109 & .108 \\
\hline & Negative & -.129 & -.090 & -.104 \\
\hline Test Statistic & & .129 & .109 & .108 \\
\hline Asymp. Sig. (2-tailed) & & $.063^{\mathrm{c}}$ & $.200^{c, d}$ & $.200^{c, d}$ \\
\hline
\end{tabular}

a. Test distribution is Normal.

b. Calculated from data.

c. Lilliefors Significance Correction.

d. This is a lower bound of the true significance.

Dari tabeldi atas dapat diketahui bahwa semua variabel yang ada didalam penelitian ini terdistribusi normal.

\subsection{Uji Mutikolineritas}

Pengujian Multikolineritas bertujuan untuk menguji apakah pada model regresi di temukan adanya korelasi antar variabel independen. Untuk mendeteksi adanya Multikolinearitas, maka dapat dilihat dengan Besaran nilai VIF (Variance Inflation Factor) dan Tolerance. Persamaan regresi yang bebas multiko adalah Mempunyai nilai VIF tidak melebihi angka 10 dan Mempunyai angka tolerance mendekati 1. Untuk hasil pengujian multikolinearitas, dapat dilihat dari tabel 1 berikut.

Tabel 4.6.

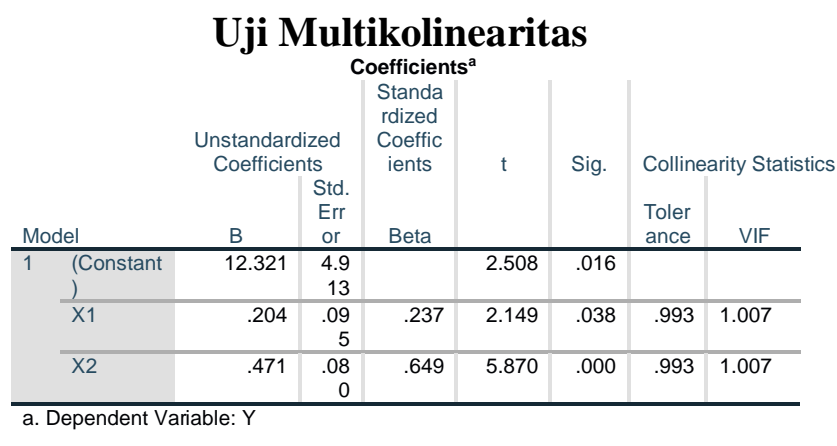

Pada tabel 4.6. terlihat nilai tolerance berada mendekati angka 1 dan nilai VIF untuk kedua variabel independen tidak melebihi angka 10, maka tidak terdapat masalah multikolinearitas.

\subsection{Uji Heteroskedastisitas}

Uji Heteroskedastisitas bertujuan untuk menguji apakah dalam model regresi terjadi ketidaksamaan varians dari residual satu pengamatan ke pengamatan, atau yang lain. Untuk melihat ada tidaknya masalah heteroskedastisitas dapat dideteksi dengan ada tidaknya pola tertentu pada grafik scater plot, apabila ada pola tertentu, seper tititik-titik yang membentuk pola teratur (bergelombang, melebar kemudian menyempit) maka telah terjadi heteroskedastisitas. Sedangkan jika tidak terdapat pola yang jelas, serta titik-titik menyebar diatas dan dibawah angka 0 dan sumbu Y, maka tidak terjadi heteroskedastisitas. Hasil dari pengujuan heteroskedastisitas dapat dilihat pada gambar 4.1 dibawah ini :

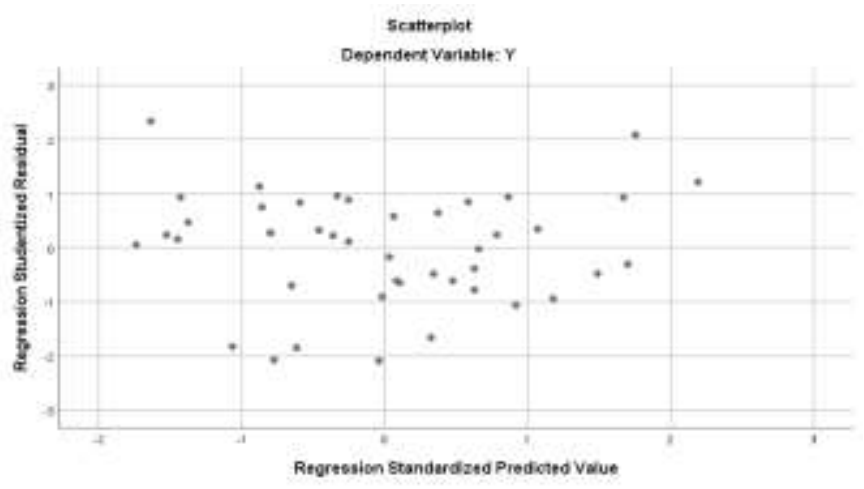

Pada gambar di atas terbukti bahwa titiktitik menyebar di atas dan di bawah titik o.

\subsection{Hasil Pengujian Hipotesis}

\section{a. Koefisien determinasi}

Hasil analisis regresi dengan bantuan program SPSS for Windows diperoleh rangkuman model seperti pada Tabel 4.9.

\section{Tabel 4.7.}

\section{Koefisien Korelasi dan Determinasi}

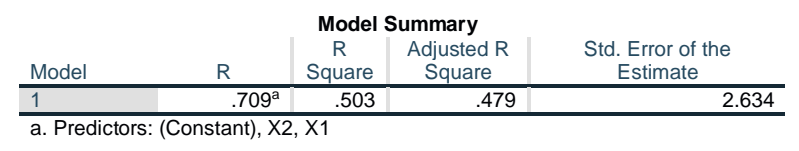

Berdasarkan tabel di atas, diperoleh nilai korelasi ganda sebesar 0,709. Nilai tersebut menunjukkan adanya hubungan positif yang 
erat antara keselamatan kerja, dan kesehatan kerja dengan kinerja. Nilai koefesien determinasi $\left(\mathrm{R}^{2}\right)$ sebesar 0,503. Hal ini menunjukkan bahwa model tersebut dapat menjelaskan variasi data yang ada sebesar 50,3 persen. Dengan kata lain, besarnya pengaruh Keselamatan kerja, Kesehatan Kerja terhadap Kinerja adalah sebesar 50,3 persen.

Pengujian secara simultan dilakukan dengan analisis varians (ANOVA- Analysis of Variance) menggunakan statistik uji-F dilakukan untuk menguji hipotesis no 1 sampai dengan nomor 4.

\section{Uji Hipotesis}

\section{Hipotesis kesatu}

Hasil perhitungan Keselamatan dan kesehatan kerja berpengaruh signifikan terhadap Kinerja diperoleh hasil seperti pada Tabel 4.10.

\begin{tabular}{|c|c|c|c|c|c|c|}
\hline & & $\begin{array}{r}\text { Tal } \\
\mathbf{U} \\
\mathbf{A}\end{array}$ & $\underset{\text { ANOVA }^{\mathbf{U}}}{\mathbf{U j i} \mathbf{F}}$ & & & \\
\hline Model & & $\begin{array}{l}\text { Sum of } \\
\text { Squares }\end{array}$ & $d f$ & $\begin{array}{l}\text { Mean } \\
\text { Square }\end{array}$ & $F$ & $\mathrm{Siq}$ \\
\hline 1 & Regression & 287.772 & 2 & 143.886 & 20.742 & $.000^{\mathrm{b}}$ \\
\hline & Residual & 284.410 & 41 & 6.937 & & \\
\hline & Total & 572.182 & 43 & & & \\
\hline
\end{tabular}

Jadi, hipotesis yang menyatakan bahwa "tidak ada pengaruh yang signifikan antara Keselamatan dan kesehatan kerja terhadap Kinerja di Dirjen Navigasi kelas I Direktorat Jenderal Perhubungan Laut Palembang" ditolak, sedangkan hipotesis yang menyatakan bahwa "Keselamatan dan kesehatan kerja berpengaruh signifikan terhadap Kinerja di Dirjen Navigasi kelas I Direktorat Jenderal Perhubungan Laut Palembang." diterima.Hal ini berarti bahwa Kinerja di Dirjen Navigasi kelas I Direktorat Jenderal Perhubungan Laut Palembang dipengaruhi oleh Keselamatan dan Kesehatan kerja secara bersamaan.

Hasil pengujian Keselamatan kerja berpengaruh signifikan terhadap Kinerja, Kesehatan Kerja berpengaruh signifikan terhadap Kinerja, terlihat seperti pada Tabel di bawah. Nilai-nilai koefesien regresi hasil pendugaan dengan metode kuadrat terkecil (Ordinary Least Square) dari pengaruh masing-masing faktor atau variabel terhadap Kinerja di Dirjen Navigasi kelas I Direktorat
Jenderal Perhubungan Laut Palembang terlihat seperti pada Tabel 4.9

.Tabel 4.9.

\begin{tabular}{|c|c|c|c|c|c|c|}
\hline \multicolumn{7}{|c|}{ Koefesien Regresi Berganda } \\
\hline \multirow{2}{*}{\multicolumn{2}{|c|}{ Model }} & \multicolumn{2}{|c|}{$\begin{array}{l}\text { Unstandardized } \\
\text { Coefficients }\end{array}$} & \multirow{2}{*}{$\begin{array}{c}\text { Standardize } \\
d \\
\text { Coefficients } \\
\text { Beta }\end{array}$} & \multirow[b]{2}{*}{$\mathrm{t}$} & \multirow[b]{2}{*}{ Siq. } \\
\hline & & B & $\begin{array}{l}\text { Std. } \\
\text { Error }\end{array}$ & & & \\
\hline 1 & (Constant) & 12.321 & 4.913 & & 2.508 & .016 \\
\hline & Keselamatan kerja (X1) & .204 & .095 & .237 & 2.149 & .038 \\
\hline & Kesehatan Kerja (X2) & .471 & .080 & .649 & 5.870 & .000 \\
\hline
\end{tabular}

Berdasarkan Tabel 4.9. dapat diambil kesimpulan sebagai berikut.

\section{Hipotesis kedua}

Nilai koefesien regresi untuk faktor Keselamatan kerja diperoleh sebesar 0,204 dengan nilai t-hitung sebesar 2,149dan $p$-value sebesar 0,038 . Karena $p$-value $<5 \%$, maka $\mathrm{H}_{0}$ ditolak. Artinya dengan kepercayaan sebesar 95\% dapat dinyatakan bahwa faktor Keselamatan kerja berpengaruh signifikan terhadap Kinerja di Dirjen Navigasi kelas I Direktorat Jenderal Perhubungan Laut Palembang.

\section{Hipotesis ketiga}

Nilai koefesien regresi untuk faktor Kesehatan kerja diperoleh sebesar 0,471 dengan nilai t-hitung sebesar 5,870 dan $p$-value sebesar 0,000 . Karena $p$-value $<5 \%$, maka $\mathrm{H}_{0}$ ditolak. Artinya dengan kepercayaan sebesar 95\% dapat dinyatakan bahwa faktor Kesehatan kerja berpengaruh signifikan terhadap Kinerja di Dirjen Navigasi kelas I Direktorat Jenderal Perhubungan Laut Palembang

Berdasarkan analisis di atas dapat disimpulkan bahwa secara simultan Keselamatan kerja dan kesehatan kerja berpengaruh signifikan terhadap Kinerja di Dirjen Navigasi kelas I Direktorat Jenderal Perhubungan Laut Palembang. Secara parsial terlihat bahwa dari dua variabel bebas faktor yang berpengaruh dominan terhadap kinerja di Dirjen Navigasi kelas I Direktorat Jenderal Perhubungan Laut Palembang adalah faktor keselamatan kerja, artinya keselamatan kerja yang semakin baik akan meningkatkan kinerja di Dirjen Navigasi kelas I Direktorat Jenderal Perhubungan. 


\section{E. KESIMPULAN}

Berdasarkan hasil analisis dan pengujian secara statistik terhadap data penelitian ini pengaruh pelaksanaan keselamatan dan kesehatan kerja terhadap kinerja kantor distrik navigasi kls I palembang direktorat jenderal perhubungan laut kementerian perhubungan dapat disimpulkan sebagai berikut:

1. Keselamatan dan Kesehatan Kerja berpengaruh terhadap Kinerja pegawai di dukung bahwa hubungan kerja anatara atasan dengan bawahan baik di Dirjen Navigasi kelas I Direktorat Jenderal Perhubungan Laut Palembang.

2. Keselamatan kerja berpengaruh positif dan signifikan terhadap Kinerja yang di dukung bahwa tingkat keamanan lingkungan kerja saya tinggi di Dirjen Navigasi kelas I Direktorat Jenderal Perhubungan Laut Palembang.

3. Kesehatan kerja berpengaruh positif dan Signifikan terhadap Kinerja Jaminan kesehatan saya diperhatikan perusahaan di Dirjen Navigasi kelas I Direktorat Jenderal Perhubungan Laut Palembang

\section{Daftar Pustaka}

Afini, 2011. Keselamatan Kerja, Keamanan Kerja, dan Lingkungan Hidup

Argama. Rizky 2006.Kesehatan dan Keselamatan Kerja sebagai Komponen Jamsostek. Jurnal Fakultas Hukum Universitas Indonesia Jakarta.

Bennet N. B Silalahi dan Rumondang B. Silalahi, 2010. Penyebab Terjadinya Kecelakaan Kerja. Jakarta (K3LH). Bandung: Arfino Ra

Dewi. Rijuna 2006. Pengaruh Keselamatan dan Kesehatan Kerja terhadapKinerja Karyawan pada PT. Ecogreen Oleochemicals Medan

Ernawati, dkk. 2009. Asuhan Keperawatan Pasien Dengan Gangguan Jiwa. Jakarta: Trans Info Media

Handara, 2002. Keselamatan dan Kesehatan Kerja. Surakarta: HARAPAN PRESS.
Husni, Lalu. 2005. Hukum Ketenagakerjaan, Edisi Revisi. Jakarta: PT. RajaGrafindo.

Kuswana, 2001. Mencegah Kecelakaan Kerja. Bandung: PTRemaja Rosdakarya

Mangkunegara. Prabu2001. Manajemen Sumber Daya Manusia Perusahaan. Bandung: PT. Remaja Rosdakarya.

Mathis Robert, Jackson John. 2002. Manajemen Sumber Daya Manusia. Jakarta: Salemba empat

Rika Ampuh Hadiguna. 2009. Manajemen Pabrik, Pendekatan Sistem untuk Efisiensi dan Efektivitas. Edisi I. Jakarta: Bumi Aksara

Sugiyono. 2014. Metode Penelitian Bisnis. Bandung: CV Alfabeta.

Suma'mur. 2009. Hiegine Perusahaan dan Keselamatan Kerja. Jakarta: CV Sagung Seto.

Undang-Undang No1 tahun 1970 Tntang Keselamatan Kerja.

Undang-Undang Republik Indonsia Nomor 3 Tahun 1992 Tentang Jaminan Soisial Teanaga Kerja

Zamzam, F., \& Aravik, H. 2016. Manajemen SDM Berbasis Syariah, Bogor: CV. RWTC Success 